\title{
Hubungan Pengaturan Emosi Positif dengan Kecemasan Menjelang Menopause pada Perempuan Pekerja
}

\author{
Maftukhatus Syarifah \& Erika Setyanti Kusumaputri \\ Program Studi Psikologi Universitas Islam Negeri Sunan Kalijaga Yogyakarta \\ Jl. Marsda Adisucipto, Yogyakarta 55281. Syarifah143@gmail.com
}

\begin{abstract}
This research is aimed at explaining the relationship between positive emotion management and pre-menopause anxiety experienced by female workers. The subjects of this research are female workers who are in pre-menopause age range in Kalirejo Village, Salaman, Magelang, Central Java. The data of this research were gained by using positive emotion management scale and premenopause anxiety scale. The technique analysis used in this research was the product moment correlation. The analysis using correlation analysis technique resulted in $\mathrm{R}$ equivalent to $-0,305, \mathrm{R}^{2}$ equivalent to 0.093 with $\mathrm{p}=0.003$. Those results show that there is indeed a significant relationship between positive emotion management and female workers' pre-menopause anxiety in Kalirejo village, Salaman, Magelang, Central Java. $\mathrm{R}^{2}$ equivalent to 0.093 shows that positive emotion management has a significance as much as 9,3\% to female workers' pre-menopause anxiety.
\end{abstract}

Key words : female worker, pre-menopause anxiety, positive emotion management,

\begin{abstract}
ABSTRAK
Penelitian ini bertujuan untuk mengetahui hubungan antara pengaturan emosi positif dengan kecemasan menjelang menopause pada perempuan pekerja. Subjek penelitian adalah perempuan pekerja dalam rentang usia menjelang menopause di desa Kalirejo, Salaman, Magelang, Jawa Tengah. Data penelitian diperoleh dengan menggunakan skala pengaturan emosi positif dan skala kecemasan menghadapi menopause. Teknik analisis statitistik yang digunakan adalah korelasi product moment. Hasil penelitian dengan menggunakan teknik analisis korelasi, diperoleh R sebesar -0,305, $\mathrm{R}^{2}$ sebesar 0.093 dengan $\mathrm{p}=0.003$. Hasil tersebut menunjukkan adanya hubungan yang signifikan antara pengaturan emosi positif dan kecemasan menjelang menopause pada perempuan pekerja di desa Kalirejo, Salaman, Magelang, Jawa Tengah. $\mathrm{R}^{2}$ sebesar 0.093 menunjukkan bahwa pengaturan emosi positif memberikan sumbangan efektif sebesar 9,3\% terhadap kecemasan menghadapi menopause pada perempuan pekerja.
\end{abstract}

Kata kunci : kecemasan menjelang menopause, pengaturan emosi positif, , perempuan pekerja 


\section{PENDAHULUAN}

Masa menopause, merupakan masa di mana seorang perempuan tidak lagi mengalami menstruasi, berkurangnya kemampuan untuk bereproduksi disertai dengan perubahanperubahan kondisi tubuh. Hal tersebut membuat seorang perempuan ketika memasuki fase menopause mengalami pergolakan-pergolakan, layaknya seorang anak yang memasuki masa remaja yang mengalami masa peralihan. Mappiane (1983) menuturkan bahwa masa menopause merupakan masa peralihan yaitu dari masa produktif menuju masa berkurangnya produktivitas seorang perempuan.

Perubahan tersebut adalah hal yang wajar, namun tidak jarang menimbulkan gangguan pada diri seorang menjelang menopause. Greenblum, Rowe, Neff dan Greenblum (2012) mengatakan bahwa pada saat perempuan mengalami menopause dapat mempengaruhi kualitas dalam hidupnya. Lebih dari 80\% wanita melaporkan menunjukan gejala secara fisik maupun psikis pada saat menjelang menoupose dengan bermacam-macam level gangguan dan mengganggu kehidupannya. Gejala yang dialami pada saat menjelang menoupase memiliki variasi dan ada jarak antara gejala psikis dan psikologis. Gejala fisik yang terlihat seperti berkeringat dimalam hari, gangguan tidur, vagina kering, inkontensia urin, penurunan berat badan. Gejala psikologis yang muncul pada wanita menjelang menoupouse adalah kelelahan, cepat marah dan kecemasan. Tercatat dalam sebuah penelitian yang menyebutkan hampir seluruh perempuan di dunia mengalami sindrom pre-menopause, data menyebutkan bahwa di negara-negara Eropa mencapai 70-80\%, Amerika 60\%, Malaysia $57 \%$, China 18\%, serta Jepang dan Indonesia $10 \%$. Catatan tersebut mengemukakan bahwa banyak dari perempuan pada masa menjelang menopause mengalami perubahan, baik perubahan tersebut dalam hal fisik maupun psikologis (Fitriana, 2011).
Perubahan atau pergeseran fisik yang dialami membawa pengaruh besar terhadap kondisi psikologis perempuan yang berada pada masa menopause. Menurut Kartono (1981) seringkali perempuan dalam masa ini mengalami kegoncangan yang membuatnya mudah sekali tersinggung, mudah marah, diliputi oleh kecemasan, murung, mudah merasakan kebingungan.

Berdasarkan penelitian Berntsson, Krantz, \& Lundberg (2003) menunjukkan bahwa perempuan menghabiskan waktu lebih banyak untuk pengasuhan anak, pekerjaan rumah dari pada laki-laki dan apabila wanita bekerja memiliki beban kerja ganda karena harus menyelesaikan pekerjaan rumah, mengasuh anak dan menyelesaikan pekerjaannya. Berbagai hasil penelitian menunjukan bahwa para wanita yang berperan ganda memiliki efek negative seperti meningkatnya stress, depresi dan gejala fisik (Barnett \& Hyde, 2001). Gangguan-gangguan ketika memasuki masa menopause dirasakan berbeda oleh perempuan satu dengan yang lainnya, dikarenakan keadaan psikis mereka juga berbeda. Bagi perempuan pekerja, memasuki masa menopause akan sangat dirasakan, mereka menjadi lebih mudah mengalami stres. Hal itu disebabkan oleh adanya dua peran dalam kehidupannya, yakni selain menjadi seorang ibu juga dia berperan mencari nafkah. Seperti yang dipaparkan oleh Simanjuntak dan Erniyati (2007) bahwa perempuan menopause pencari nafkah mudah mengalami stres yang bersumber dari lingkungan kerja, tuntutan kerja, tanggung jawab kerja, lingkungan fisik tempat kerja, hubungan yang kurang baik antar manusia, kurangnya pengetahuan dan peningkatan jenjang karir, dan perasaan kurang aman ketika bekerja menjadi alasannya.

Berdasarkan pendapat di atas, dengan mengarah kepada lingkungan kerja, serta tuntutan kerja, kita ketahui bahwa seorang buruh identik dengan masyarakat ekonomi menengah ke bawah, dengan tempat atau lingkungan pekerjaan 
yang tidak tetap serta penghasilan kurang menjadi pemacu stress tersendiri. Hal ini juga didukung oleh penelitian Aprillia dan Puspitasari (2007) yang menunjukkan menyebutkan ada beberapa faktor yang dapat menyebabkan kecemasan seseorang pada usia-usia menjelang menopause salah satunya adalah faktor ekonomi, di mana seseorang dengan ekonomi rendah akan lebih mudah mengalami kecemasan.

Para pekerja buruh yang mana mereka dituntut lebih banyak menggunakan fisik untuk bekerja dengan pekerjaan yang berat, dengan kondisi fisik mulai menurun ketika memasuki masa menopause, pastilah mereka sangat merasakan perubahan yang mereka alami. Terlebih perubahan fisik tersebut dapat mempengaruhi perubahan pendapatan seorang buruh, yang kemudian dapat menimbulkan kecemasan pada diri mereka. Hal tersebut peneliti temukan dari hasil wawancara pada perempuan menjelang menopause yang masih bekerja di desa Kalirejo. Hasil wawancara menunjukkan bahwa mereka yang merasakan adanya perubahan-perubahan. Kebanyakan dari mereka merasakan peruabahan mulai dari segi fisik seperti mudah lelah, nyeri pada persediaan dan kepala sering serta dari beberapa mereka mulai merasakan tremor. Selain fisik mereka juga merasakan perubahan pada kondisi psikis. Perubahan tersebut antara lain merekan menjadi was-was, tegang, mudah merasa khawatir, kewaspadaan meningkat, konsentrasi menurun, mudah lupa, mudah tersinggung dan seringkali gelisah tanpa mengetahui penyebabnya. Berdasarkan data tersebut, bisa dikatakan bahwa perempuan yang sedang memasuki masa menopause mengalami perubahan-perubahan baik dalam hal fisik maupun psikisnya. Melihat beberapa cirri yang telah dipaparkan diatas bisa digolongkan bahwa responden mengalami kecemasan.

Kecemasan sendiri merupakan bentuk reaksi terhadap suatu hal yang dianggap oleh seseorang sebagai sesuatu yang mengancam dirinya. Kecemasan pada perempuan menopause timbul karena adanya perubahan fisik, perubahan fisik tersebut karena adanya perubahan tingkat hormone yaitu penurunan hormone esteregon yang kemudian hal tersebut berpengaruh pada kondisi psikisnya (The American College of Obstetricians dan Gynecologists, 2004) . Kecemasan menjelang menopause menurut Rostriana dan Taganing (2009) merupakan suatu bentuk kekhawatiran akibat adanya perubahanperubahan, baik dari segi fisik maupun psikis, di mana ditandai dengan adanya gejala-gejala yang muncul dari segi kognitif, afektif, somatik, dan motorik.

Banyak faktor yang mempengaruhi kecemasan menjelang menopause. Seperti yang dipaparkan oleh Atamimi(Oktiviani, 2012) antara lain Pertama adanya pemikiran bahwa menjelang menopause usia menjadi tua, keriput, cerewet, bawel, pencemas. Kedua perasaan kesepian karena ditinggal anak-anaknya yang sudah dewasa. Ketiga hilang daya tarik, dan menurunnya aktifitas seksual, sehingga membuat perempuan merasa suami tidak lagi tertarik pada dirinya. Keempat goncangan emosi yang berat yang berdampak pada kondisi kesehatan dan kesejahteraan jiwa.

Namun, pada penelitian ini pengaturan emosi positif menjadi variabel yang mempangaruhi kecemasan menjelang menopause. Hal tersebut didasarkan pada beberapa faktor yang mempengaruhi kecemasan menjelang menopause yang dipaparkan oleh Fitriana (2011) dalam penelitiannya menyebutkan bahwa kecemasan pada perempuan jelang menopause atau masa klimaterium timbul karena adanya penekanan emosi serta sebab-sebab fisik yang berhubungan dengan masa jelang menopause.

Berdasarkan penelitian Fitriana (2011) menyebutkan bahwa kecemasan pada perempuan jelang menopause atau masa klimaterium timbul karena adanya penekanan emosi yang menyebabkan terjadinya konflik 
emosi serta sebab-sebab fisik yang berhubungan dengan masa jelang menopause. Munculnya konflik emosi pada seorang perempuan menjelang menopause mengakibatkan munculnya emosi negatif yang berakibat seorang perempuan mengalami kecemasan. Maka perlu adanya pengaturan emosi positif untuk meminimalisir emosi negatif yang muncul. Alasan memilih pengaturan emosi positif adalah ketika seseorang fokus pada sesuatu yang positif, maka secara tidak langsung hal-hal yang negatif dapat diminimalisir (Rasyid, 2010).

Pengaturan emosi positif menurut Feldman, dkk (2008) adalah mengenai kemampuan individu merespon emosi positif di mana ada beberapa bentuk respon, yaitu respon yang fokus terhadap daya afektif berhubungan dengan kemampuan individu mengenal emosi yang ada dalam dirinya.

\section{METODE PENELITIAN}

Sampel penelitian yang digunakan dalam penelitian ini adalah bagian dari populasi yaitu perempuan dengan rentan usia 45-50 tahun atau masih dalam jenjang masa memasuki usia menopause dan masih aktif bekerja sebagai buruh yang tinggal di desa Kalirejo, kecamatan Salaman, kabupaten Magelang. Sampel diambil $50 \%$ dari jumlah populasi dengan cara mendatangi secara langsung dusun-dusun yang menjadi tempat penelitian, hingga terkumpul 50\% yang sesuai dengan karakteristik pada populasi.

Penelitian ini menggunakan alat pengambilan data berupa skala, yaitu skala pengaturan emosi positif dan skala kecemasan menjelang menopause. Skala pengaturan emosi positif disusun peneliti sendiri dengan mengacu pada teori yang dipaparkan oleh Feldman (2008) . Skala ini terdiri dari 48 aitem yang disusun untuk mengukur aspek-aspek pengaturan emosi positif dengan rincian sebagai berikut
Table 1. Indikator skala pengaturan emosi positif

\begin{tabular}{lcl}
\hline No & Aspe k-a spek & \multicolumn{1}{c}{ Indikator } \\
\hline 1. & Emotion focus & $\begin{array}{l}\text { kemampuan mengenal } \\
\text { emosi positif, kemampuan } \\
\text { mengungkapkan emosi } \\
\text { positif }\end{array}$ \\
2. & Selffocus & $\begin{array}{l}\text { fokus pada masa depan, } \\
\text { kepercayaan diri }\end{array}$ \\
3. & $\begin{array}{l}\text { Cognitive } \\
\text { responses }\end{array}$ & $\begin{array}{l}\text { kontrol ekspresi emosi, } \\
\text { kontrol kepercayaan diri }\end{array}$ \\
\hline
\end{tabular}

Skala kecemasan menjelang menopause disusun peneliti dengan mendasarkan pada analisis fungsional kecemasan yang diungkap oleh Blackburn dan Davidson (1995), skala terdiri dari 45 aitem yang disusun berdasar aspek-aspek pada tabel 2.

Validitas yang akan dipenuhi untuk alat ukur penelitian ini adalah validitas isi (content validity) yaitu validitas yang dapat menunjukkan sejauh mana aitem-aitem dalam tes dapat mencakup kawasan isi yang hendak diukur. Validitas ini ditegakkan melalui analisis rasional (logical validity) terhadap isi tes (Azwar, 2012). Validitas alat ukur dalam penelitian ini menggunakan proffesional judgement, yaitu dilakukan oleh dosen pembimbing skripsi, dengan tujuan untuk mengoreksi aitem-aitem masing-masing skala penelitian.

Proses selanjutnya adalah proses analisis aitem untuk menyeleksi aitem-aitem mana yang dapat digunakan untuk menyusun alat ukur penelitian. Prinsip kerja yang dijadikan dasar seleksi aitem, dalam hal ini adalah memilih aitemaitem yang fungsi ukurnya sesuai dengan fungsi ukur skala sebagaimana dikehendaki oleh penyusunnya. Dengan kata lain dasarnya adalah memilih aitem yang valid, Azwar (2005) mengatakan aitem dianggap valid ketika nilai koefisien lebih dari 0,30. Namun, dalam penelitian ini koefisien validitas untuk menentukan aitem gugur adalah 0.250 , dalam arti aitem yang 
memiliki koefisien dibawah 0.250 dianggap tidak

valid dan digugurkan.

Tabel. 2. Indikator skala kecemasan menghadapi menopause

\begin{tabular}{|c|c|c|}
\hline $\mathbf{N}$ & Aspek-aspek & Indikator \\
\hline 1 & Suasana hati & $\begin{array}{l}\text { 1. Mudah marah, } \\
\text { 2. merasa cemas, } \\
\text { 3. kesedihan }\end{array}$ \\
\hline 2 & Pikiran (kognitif) & $\begin{array}{l}\text { 1. Mudah merasa khawatir, } \\
\text { 2. sulit berkonsentrasi, } \\
\text { 3. sensitif }\end{array}$ \\
\hline 3 & Perilaku (behavioral) & $\begin{array}{l}\text { 1. Mudah merasa gelisah } \\
\text { 2. kewaspadaan yang berlebih, } \\
\text { 3. mengeluh }\end{array}$ \\
\hline 4 & Motivasi & $\begin{array}{ll}1 & \text { Menghindari situasi, } \\
2 & \text { kurang minat dalam bekerja, } \\
3 & \text { ketergantungan }\end{array}$ \\
\hline 5 & Gejala biologis & $\begin{array}{l}1 \text { Nyeri pada persendian, } \\
2 \text { mudah merasa pusing, } \\
3 \text { mudah lelah } \\
\text { mlah }\end{array}$ \\
\hline
\end{tabular}

Table 3. Reliabilitas skala

\begin{tabular}{lcc}
\hline \multicolumn{1}{c}{ Skala } & Jumlah aitem valid & Koefisien $\boldsymbol{\alpha}$ (alpha) \\
\hline $\begin{array}{l}\text { Skala kecemasan menjelang } \\
\text { menopause }\end{array}$ & 32 & 0.890 \\
\begin{tabular}{l} 
Skala pengaturan emosi positif \\
\hline
\end{tabular}
\end{tabular}

Sesuai dengan hipotesis yang diajukan dan berdasarkan identitas variabel penelitian, jenis data, dan tujuan penelitian, yaitu untuk menguji secara empirik hubungan antara pengaturan emosi positif dengan kecemasan menjelang menopause pada perempuan pekerja di desa Kalirejo, maka statistik yang digunakan adalah teknik korelasi product moment.

\section{HASIL DAN PEMBAHASAN}

Hasil dari pengujian hipotesis penelitian ini menunjukkan bahwa ada hubungan negatif yang signifikan antara pengaturan emosi positif dengan kecemasan menjelang menopause pada perempuan pekerja di desa Kalirejo, Salaman, Magelang, Jawa Tengah. Hal tersebut ditunjukkan dengan koefisien regresi $(\mathrm{R})$ sebesar -0.305 dengan $p=0.003$, sehingga hipotesis yang diajukan dalam penelitian ini dapat diterima.

Nilai $R=-0,305$ merupakan nilai besaran korelasi antara pengaturan emosi positif dengan kecemasan menjelang menopause. Nilai tersebut menunjukkan bahwa ketika seorang perempuan menjelang menopause mampu berfokus pada 
emosi terlebih emosi positif dalam diri atau mengetahui emosi positif, kemudian mampu berfokus terhadap apa yang ada dalam diri juga mampu menanggapi respon kognitifnya secara benar dapat meminimalisir munculnya kecemasan. Kecemasan yang ditandai dengan terganggunya suasana hati atau kondisi emosi diri, pikiran, perilaku, motivasi serta gejala biologis.

Berdasarkan hasil tersebut, penelitian ini menunjukkan bahwa rendahnya kecemasan menjelang menopause seseorang dipengaruhi oleh pengaturan emosi positif yang baik pada diri seseorang. Penelitian ini menunjukkan variabel pengaturan emosi positif memberikan sumbangan efektif terhadap kecemasan menjelang menopause ditunjukkan dengan koefisien determinasi $\left(\mathrm{R}^{2}\right)$ sebesar 0.093 atau sebesar 9,3\%, sehingga dapat diartikan bahwa pengaturan emosi positif dapat mempengaruhi kecemasan menjelang menopause pada diri seseorang. $\mathrm{R}^{2}$ sebesar 9,3\% menunjukkan bahwa masih terdapat 90,7\% faktor lain yang tidak diidentifikasikan di dalam penelitian ini yang juga mempengaruhi kecemasan menjelang menopause pada diri seseorang.

Menopause terjadi pada seorang perempuan bisa terjadi secara cepat atau bisa juga lambat. Hal tersebut dipengaruhi oleh beberapa faktor dari dalam maupun faktor dari luar. Blackburn IVY. Marie \& K. M. Davidson (Larasati) menyebutkan faktor dari dalam antara lain usia awal haid, jumlah anak, kondisi jiwa dan pekerjaan. Sedangkan faktor dari luar adalah kebiasaan merokok, penggunaan obat kontrasepsi, daerah tempat tinggal dan sosialekonomi seseorang.

Faktor-faktor tersebut bisa menjadi pemicu terjadinya kecemasan, di mana faktor mengenai pekerjaan dan status sosial-ekonomi kerapkali menjadi pemicu terjadinya kecemasan. Subjek penelitian yang bekerja sebagai buruh dengan kondisi ekonomi berada pada taraf menengah ke bawah begitu merasakan perubahan ketika memasuki masa menopause, yang berakibat pada munculnya kecemasan. Namun, kondisi yang demikian tidak akan terjadi bilamana mereka mampu merubah pola fikir negatif ke positif yang berpengaruh pada kondisi emosi positif kemudian mengontrol emosi positif tersebut. Karena dengan senantiasa menjaga emosi positif, secara tidak langsung dapat meminimalisir emosi negatif (Rasyid M.E. 2010).

Faktor-faktor lain yang menjadi penyebab kecemasan menjelang menopause antara lain kekhawatiran yang tidak mendasar yang bersumber dari perubahan dan kemunduran fisik menjadi penyebab kecemasan yang dialami wanita, proses kognisi dan pandangan negatif tentang menopause (Rostriana dan Taganing 2009). Pandangan yang salah terhadap menopause menyebabkan munculnya emosi negatif yang mengarah pada kecemasan. Untuk meminimalisir emosi negatif bisa dengan mengubah pandangan ke pandangan positif yang memunculkan emosi positif, kemudian perlu adanya pengaturan emosi positif.

Hal tersebut sama dengan manfaat emosi terhadap kecemasan yang diungkapkan oleh Frederikson (Sholichatun) di mana emosi negatif cenderung mempersempit cadangan pikirantindakan sesaat dengan cara mempersiapkan individu untuk berperilaku dalam cara tertentu misalnya ketika seorang takut dia akan bersembunyi, ketika cemas akan melakukan kegiatan yang menghilangkan rasa cemasnya. Sebaliknya, beragam rentang emosi-emosi positif seperti kegembiraan, interes, kepuasan hati memperluas cadangan pikiran-tindakan serta melapangkan rentang kognisi dan perilaku yang menghampiri pikiran individu. Dengan kata lain emosi positif membantu individu memperluas daya kognitif dan rasa dalam diri sehingga lebih merasa tenang kemudian kecemasan menjelang menopause menurun. 


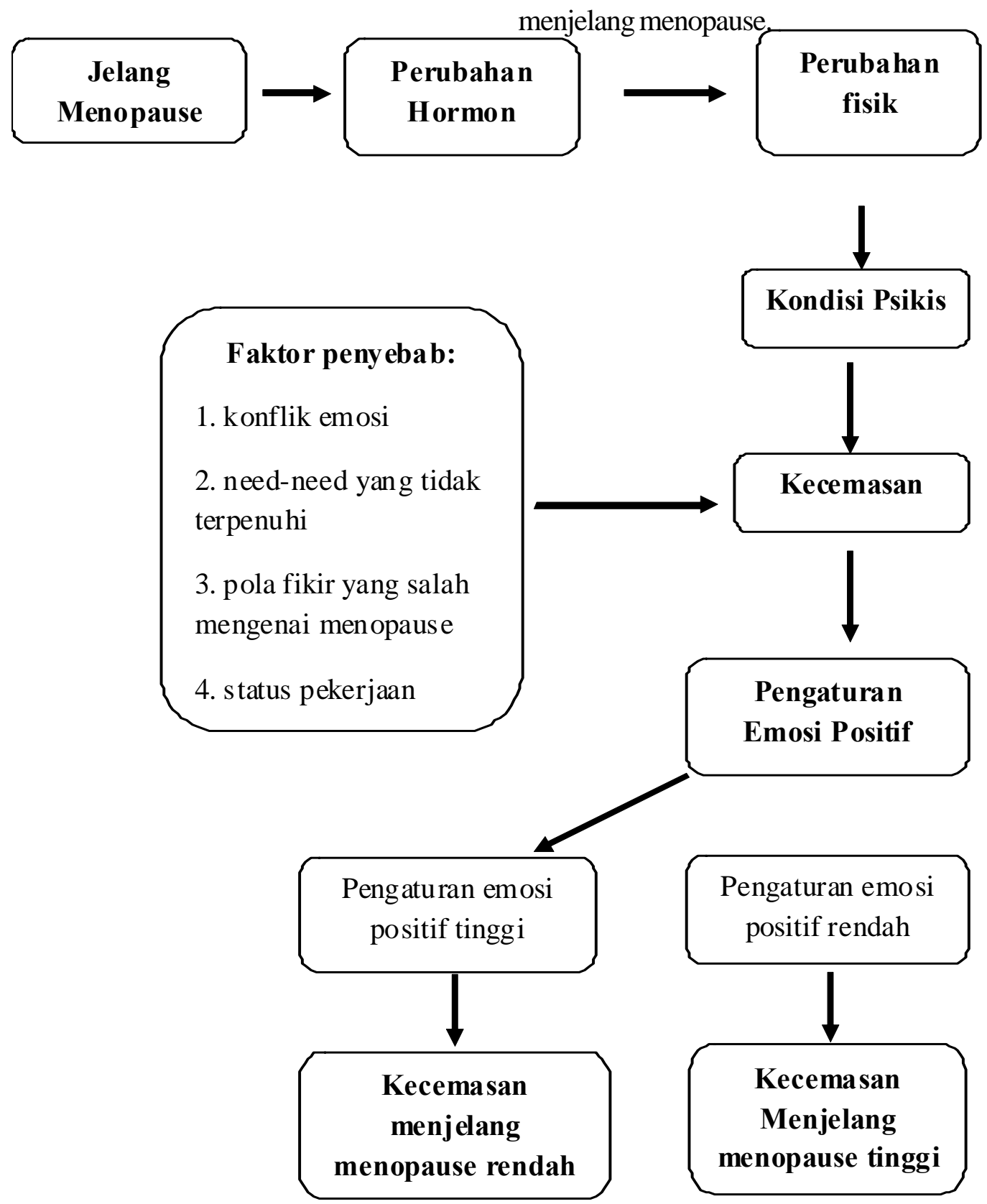

Gambar 1. Dinamika hubungan pengaturan emosi positif dengan kecemasan menjelang menopause

\section{SIMPULAN}

Pengaturan emosi positif mempunyai peran dalam rendahnya tingkat kecemasan pada perempuan menjelang menopause. Pengaturan emosi positif yang dilakukan secara terus-menerus dan fokus pada emosi positif, mampu meminimalisir kecemasan menjelang menopause yang merupakan bentuk dari emosi negatif. Dengan pengaturan emosi positif, mengenal emosi positif dalam diri, kemudian mengungkapkannya secara benar, dan juga mampu mengelola emosi positif dalam dirinya, berdampak pada rendahnya tingkat kecemasan 


\section{DAFTAR PUSTAKA}

Aprillia, N.I dan Puspitasari, N. (2007). Faktorfaktor yang Mempengaruhi Tingkat Kecemasan pada Perempuan Perimenopause. Artikel. Bagian Biostatistika dan Kependudukan Fakultas Kesehatan Masyarakat Universitas Airlangga. Diunduh pada tanggal 7 Juni 2012.

Azwar, S. (2005). Penyusunan Skala Psikologi. Yogyakarta : Pustaka Pelajar.

Azwar, S. (2012). Reliabilitas dan Validitas. Yogyakarta: Pustaka Pelajar.

Barnett, R. C \& Hyder, J.S. (2001). Women, Men, Work and Family. The American Psychologi Association. DOI: $\quad 10.1037 / / 0003-$ 066X.56.10.781

Blackburn, IVY. Marie \& K. M. Davidson. (1995). Cognitive Therapy for Depression and Anxiety. USA: Blackwell Science. Diunduh pada tanggal 29 September 2012. http:// amazon.com

Berntsson, L,.Lundberg, U,. \& Krantz, G. (2003). Gender Differences in WorkHome interplay and Symptom Perception Among Swedish WhiteCollar Employees. Journal Epidemiol Community Health. Doi: 10.1136/jech.2005.042192.

Feldman, G. C., Jutta, J \& Sheri, L. J. (2008). Responses to Positive Affect: a Self Report Measure of Rumination and Dampening. Cognitive Therapy and Research. Article. Diunduh pada tanggal 1 Juli 2013. http:// link.springer.com/article
Fitriana, Y. (2011). Fenomena Kecemasan Wanita dalam Menghadapi Masa Klimaterium di Rt 01 Rw 01 Kelurahan Candi Semarang. Jurnal Keperawatan dan Kebidanan (JIKK) Vol 1 No 5 Desember 2011. Diunduh pada tanggal 7 Juni 2012.

Greenblum, C.A, Rowe, M.A, Neff, D.F \& Greenblum, J.S. (2012). Midlife Women: Symptoms Associated with Menopausal Transition and Early Postmenopause and Quality of Life. The Journal of The North America Menoypase Society. DOI; 10.10097/ Vol 20, No 1.

Kartono, K. (1981). Psikologi Wanita, wanita sebagai ibu \& nenek. Bandung: Mandar Maju.

Larasati, T. Jurnal Kualitas Hidup pada Wanita yang sudah memasuki Masa Menopouse. Fakultas Psikologi Universitas Gunadarma. Artikel. Diunduh pada tanggal 7 Juni 2012.

Mappiare, A. (1983). Psikologi Orang Dewasa bagi Penyesuaian dan Pendidikan. Surabaya: Usaha Normal.

Oktaviani, W. (2012). Hubungan antara Pengetahuan tentang Menopause dengan Kecemasan Menghadapi Menopause pada Ibu Rumah Tangga. Skripsi (tidak diterbitkan). Yogyakarta: Universitas Gadjah Mada.

Rasyid, M. E. (2010). Asyiknya Berfikiran Positif (Kisah dan Langkah Nyata untuk Membentuk Mental Positif Agar Sukses Tanpa Batas). Jakarta: Penerbit Zaman.

Rostriana, T., dan Ni Made T. K. (2009). Kecemasan pada Wanita yang 
Menghadapi Menopause. Jurnal Psikologi. Vol. 3. No. 1 Desember 2009. Diunduh tanggal 17 Juli 2012.

Sholichatun, Y. Hidup Setelah Menikah Mengurai Emosi Positif dan

Resiliensi pada Wanita Tanpa Pasangan. Fakultas Psikologi Universitas Negeri Islam Malang. Artikel. Diunduh pada tanggal 5 Juli 2012.
Simanjuntak., \& Erniyati. (2007). Adaptasi Psikososial Wanita Menopause Pekerja dan Bukan Pekerja di Perumnas mandala Kecamatan Percut Sei Tuan Deli Serdang. Jurnal Keperawatan Rufaidah Sumatra Utara Vol 2. No 2 November 2007. Diunduh 22 Juni 2011.

The American College of Obstetricians and Gynecologists (2004). Genitourinary tract changes. Obstet Gynecol;104 (suppl 4):56S-61S. 